NBER WORKING PAPER SERIES

\title{
LANGUAGE-SKILL COMPLEMENTARITY: RETURNS TO IMMIGRANT LANGUAGE ACQUISITION
}

\author{
Eli Berman \\ Kevin Lang \\ Erez Siniver \\ Working Paper 7737 \\ http://www.nber.org/papers/w7737
NATIONAL BUREAU OF ECONOMIC RESEARCH 1050 Massachusetts Avenue
Cambridge, MA 02138 \\ June 2000
}

Lang acknowledges the support of NSF grant SBR-9515052. We thank the Falk Institute for editorial support. We benefited from the comments of Dan Ackerberg, Michael Beenstock, Peter Doeringer, Maggie Eisenstaedt and participants in seminars at the Institute for Race and Social Division and a labor lunch at Boston University. The views expressed herein are those of the authors and not necessarily those of the National Bureau of Economic Research.

(C) 2000 by Eli Berman, Kevin Lang, and Erez Siniver. All rights reserved. Short sections of text, not to exceed two paragraphs, may be quoted without explicit permission provided that full credit, including (C) notice, is given to the source. 
Language-Skill Complementarity: Returns to Immigrant Language Acquisition

Eli Berman, Kevin Lang, and Erez Siniver

NBER Working Paper No. 7737

June 2000

JEL No. C81, F22, J15, J31, N35

\begin{abstract}
We examine the effect of language acquisition on the growth of immigrants' earnings. We gathered data on recent Soviet immigrants to Israel that include retrospective questions on earnings and language ability on entry into their current job. Language acquisition is found to interact positively with occupation level. Immigrant programmers and computer technicians have a return to tenure about three percentage points higher than that of natives; improved Hebrew language skills account for between $2 / 3$ and $3 / 4$ of that differential wage growth. In contrast, construction workers and gas station attendants have no convergence of wages to those of natives and language acquisition has no discernible effect on their wages. For these less skilled workers the estimated "return" to Hebrew proficiency in the cross-section is entirely due to ability bias. This finding may invite a reinterpretation of other studies on the returns to language acquisition for low wage immigrants.
\end{abstract}

Eli Berman

Department of Economics

Boston University

270 Bay State Road

Boston, MA 02215

and NBER

eli@bu.edu

Erez Siniver

Management Institute

Tel Aviv
Kevin Lang

Department of Ecnomics

Boston University

270 Bay State Road

Boston, MA 02215 


\section{LANGUAGE-SKILL COMPLEMENTARITY: \\ RETURNS TO IMMIGRANT LANGUAGE ACQUISITION}

\section{Introduction}

There is general agreement that immigrants experience faster wage growth than do native workers. One explanation for this finding is that over time immigrants learn the host country language and thereby become more productive in the labor market. Considerable research supports the view that in a cross-section regression language fluency can account for a significant portion of the rate of wage convergence.

However, the cross-sectional evidence is subject to several problems. On the one hand, both the correlation between fluency and earnings and the correlation between time in the host country and fluency may be partly or totally spurious, thereby generating upwards-biased estimates of the importance of fluency for wage convergence. On the other hand, measures of fluency are very noisy, biasing estimated coefficients downwards.

The major alternative explanation for convergence is that recent immigrants, like young natives, engage in considerable job shopping. Immigrants exhibit considerable job mobility (Lalonde and Topel, 1991; Eckstein and Weiss, 1998). (They may be engaged in BurdettJovanovic job-matching, which is productive, or simply pursuing rents.) Except for recent labor market entrants, native workers will have had more time to shop for jobs than otherwise comparable immigrants and will therefore have a smaller marginal return to job search. Of course, job shopping and language may be complementary - knowledge of the native language may facilitate job search; similarly, the type of/selection of jobs with which workers are best matched may change rapidly as they acquire fluency in the language of the host country. 
It is important to measure accurately the effect of language acquisition on wages. If growing fluency accounts for a significant portion of wage, receiving countries can speed up such convergence by supporting effective language programs. On the other hand, if language is relatively unimportant, language programs may be economically wasteful or merely a disguised form of welfare.

In this paper we use a unique data set collected by one of the authors to cast light on the role of language acquisition in wage convergence within jobs. The data set contains measures of fluency and wages, both currently and when the individual started the job, thereby allowing us to measure the effect of changing fluency on the change in wage. Moreover, since we follow workers within jobs, we can distinguish wage growth within jobs from wage growth due to job changes.

We study immigrants from the former Soviet Union (henceforth referred to as Russians) to Israel, who were employed in one of four occupations in Israel (gas station attendant, construction worker, computer technician, programmer). We find that Hebrew fluency had almost no effect on wage growth in the low-skill occupations (gas station attendant, construction worker). Moreover, these occupations show no evidence of wage convergence. In contrast, computer technicians and programmers show evidence of considerable wage convergence, much of which can be accounted for by their increasing Hebrew fluency.

We interpret our findings as strong evidence for an effect of language on earnings, as it is free of a heterogeneity bias in levels. The contrast between the lack of estimated returns to language for low-skill workers and high returns for high-skill workers is interesting for two reasons. First, it provides some evidence against a heterogeneity bias in ability to learn quickly. More importantly, it establishes evidence for an intuitively plausible result: that language complements occupational skills.

Section 2 reviews the literature. Section 3 provides an overview of immigration to Israel 
from the former Soviet Union. Section 4 describes the data; Section 5 describes the methodology. Section 6 provides results and Section 7 concludes.

\section{Literature Review}

Since the pioneering work of Chiswick (1978) and related work by Carliner (1980) it has been widely recognized that the earnings of immigrants increase more rapidly than those of natives. Subsequent work by Borjas (1985) engendered a lively debate regarding whether immigrants tend to surpass equivalent natives and about the extent of bias in cross-sectional estimates of catch-up (see, for example, Friedberg, 1992; Duleep and Regets, 1996). Nevertheless, researchers generally agree that immigrant wages rise relative to native wages as the time spent by the immigrant in the receiving country increases (Borjas, 1994).

Borjas (1994) argues that we know relatively little about why wages of immigrants and natives converge. Although there are a number of plausible hypotheses, the only one that has been extensively studied is the view that immigrants' relative wages rise as they master the language in the receiving country. There is considerable evidence that knowledge of the host country language is correlated with higher wages with years since migration. ${ }^{1}$

However, Borjas argues that this evidence is not entirely convincing because English proficiency and earnings might be correlated simply because the more able workers are more likely to speak English and to earn more. He goes on to recognize that some researchers (e.g. Chiswick and Miller, 1992) have tried to correct for the potential endogeneity of language knowledge by using instrumental variables techniques, but he questions the exogeneity of the identifying instruments. More recent work (Dustmann and van Soest, 1998a uses father's education as an instrument for language. The authors argue that immigrants do not obtain

\footnotetext{
${ }^{1}$ See Chiswick (1998) and the references therein as well as Carliner (1995, 1996), Chiswick and Miller (1999), and Hayfron (1997).
} 
networks through their parents and thus education is exogenous to wages. However, to the extent that parental education is correlated both with unobserved investments in children's human capital other than language and with unmeasured ability, the exogeneity assumption is questionable.

There is also reason for concern that estimates of the effect of years since migration on language knowledge are biased. Dustmann (forthcoming) finds that individuals who intend to spend less time in the host country are less likely to know the host country language. If immigrants who fail to master the host language return to their home country, or if those whose immigration is temporary fail to learn the language, the estimated effect of time spent in country on language facility will be biased.

Finally, if the type of immigrants admitted to a country changes over time, differences in language knowledge may reflect cohort rather than time-in-country effects. Carliner (2000) addresses this problem by using synthetic cohorts. He establishes that within a cohort, language fluency increases with time spent in the United States. However, synthetic cohorts cannot be used to control for the effect of presumably selective return migration on the estimates.

So far we have concentrated on reasons why estimates of the effect of language acquisition on the convergence of immigrant and native earnings may be biased upwards. It is important, however, to note that the estimates might also be biased downwards owing to measurement error. Language knowledge is virtually always measured on the basis of self-reported fluency grouped into a small number of crude categories. Individuals may vary in their assessment of what constitutes "good" or "very good" knowledge of the native language. In addition, individuals may themselves give inconsistent answers. Dustmann and van Soest (1998a,b) analyze knowledge of German in the GSOEP (German Socio-Economic Panel). Most of the immigrants in the GSOEP survey had been in Germany 15 years or more, so that, not surprisingly, the sample shows little or no improvement in German fluency over time. This 
feature of their sample makes it particularly useful for studying the effect of measurement error on the estimated return to fluency.

Dustmann and van Soest show that for this sample, reported knowledge of German is unchanged from one survey to the next in $58 \%$ of the cases, and is as likely to decline from one survey to the next as it is to improve. They also show that within-individual variation accounts for $28 \%$ of the variation in reported fluency. Since some of the between-individual variation in reported fluency is also due to measurement error, the fluency variable is very noisy. Using reported fluency from other years to instrument for current reported fluency almost triples the estimated affect of fluency on earnings and reduces the estimated effect of years since migration on earnings to close to zero. ${ }^{2}$

While our discussion so far has treated the effect of language as constant across individuals, it is plausible that the return to language differs across individuals. Those studies that allow the return to vary across education or occupation groups confirm this (see for example Dustmann and van Soest, 1998b; Carliner, 1996; Hayfron, 1997).

In the Israeli context, Eckstein and Weiss (1998) find faster wage growth among more skilled immigrants than among the less skilled. They term this "rising prices of imported skills," though they remain agnostic as to whether this is an increase in demand for imported skill or an increase in its quality. ${ }^{3}$ Beenstock (1993) reports that both education and working in an occupation which requires post-secondary education are predictors of Hebrew ability for previous cohorts of immigrants. He also reports that Hebrew ability is a predictor of employment. Thus it is plausible that increasing fluency raises the relative productivity of skilled workers by making their human capital more usable. The combination of faster wage

\footnotetext{
${ }^{2}$ Note that since within-individual variation in fluency appears to be almost entirely due to measurement error, Dustmann and van Soest cannot use the panel nature of the data to correct for the other biases we discuss here.

${ }^{3}$ Eckstein and Weiss (1998), p. 7.
} 
growth and quicker improvement of Hebrew among more skilled workers does not necessarily imply that language complements skill. There is evidence of considerable job turnover among immigrants. Skilled workers may take more time to acquire information about appropriate matches in the labor market. Matching takes time. Learning a language also takes time. Therefore, fluency and match quality may well be correlated, but the relation need not be causal.

To summarize, an ideal study of the effect of language on the assimilation of immigrants would address at least the following four issues: (i) Correlation between unobserved ability and fluency, (ii) spurious correlation between fluency and time in host country, (iii) measurement error, and (iv) inter-individual variation in the return to language fluency. Moreover, it would distinguish between the returns to job-shopping and to language.

The data and approach we use in the following sections do not allow us to fully address all these issues. Nevertheless, we are able largely to mitigate their effects by using retrospective information on wages and linguistic proficiency within the same job. We will argue that our data are relatively (although not completely) free of the sorts of bias discussed above. Before discussing our data and approach in detail, we provide a brief discussion of Russian immigration to Israel.

\section{Russian Immigration to Israel}

In 1989 the Soviet Union, in a major policy shift, removed restrictions on and allowed free migration of Jews to Israel, while the U.S. reduced access to Soviet immigrants through the mechanism of refugee status. As a result, a large wave of immigrants began arriving in Israel in the Fall of 1989. By 1995 about six hundred thousand immigrants had arrived, increasing the Israeli population by $12 \%$.

It is worth stressing that, in contrast to the high cost of migration for earlier waves, who 
faced confiscation of property and often lost their jobs when applying for exit permits, migration to Israel since 1989 has been much easier. Recent immigrants face virtually no exit restrictions in the former Soviet Union, have enjoyed surprisingly positive economic outcomes in Israel and arrived in a country with a significant Russian subculture. Immigrants from the former Soviet Union have been able to improve their standards of living fairly quickly with relatively little culture shock (Beenstock and ben Menahem, 1995; Friedberg, 1997). The low cost of and high return to migration for the current wave make them an unusual group of immigrants in the sense that self-selection is probably much less important for this group than for other immigrants studied in the literature (Chiswick 1978; Borjas 1987).

\section{The Data}

Our primary data source is the Occupation Survey (OS), a survey of male workers in workplaces with a high proportion of immigrants in 1994, 5 years into the large wave of migration from the former Soviet Union to Israel. ${ }^{4}$ The survey covered 348 immigrants who had arrived since 1989, and 603 natives working in the same occupations and workplaces.

The most valuable features of these data are retrospective questions on earnings and language ability on entry into the current job. This method is consistent with recent insights from survey design (Belli et al., 1999) which stress the importance of focusing on significant events in minimizing measurement error in responses. The idea is that in a retrospective question, earnings and language ability will be much easier to recall for the date of hire than for an arbitrary date, such as January 1 of last year.

For comparison, we draw on the Israel Central Bureau of Statistics' Income Survey (IS), a long form applied to outgoing rotations of the Labour Force Survey. This is a household survey

\footnotetext{
${ }^{4}$ For details see Siniver (1998).
} 
which currently samples about 7,000 households per year, reporting detailed information on individuals aged 15 and older. ${ }^{5}$

Table 1 reports descriptive statistics for the OS, with a sample of immigrants from the IS included for comparison. Male immigrants in the OS are surveyed in four occupation groups: programmers, computer technicians, construction workers and gas station attendants. ${ }^{6}$ This grouping was designed to cover both high- and low-skill ends of the occupational distribution of immigrants. For comparison, about $22 \%$ of recent male Soviet immigrants are scientists, academics, professionals and technicians, the equivalent high-skill occupation groups; about $12 \%$ are unskilled workers in services or production workers in manufacturing. which are roughly equivalent low-skill occupations. The OS tended to survey younger workers, with a mean age of 30 , almost ten years younger than the IS mean. OS workers average 0.8 years less education and $14 \%$ lower earnings. All these differences seem to be mainly due to the occupations chosen. Natives in the OS averaged 31.4 years of age and 12.4 years of education (not shown). The mean Soviet immigrant in both data sets had been in Israel for 3 years.

Job tenure in the OS is short, averaging 1.3 years. This is due both to the short interval since migration and to high turnover in construction and gas stations. (See Table 5 for descriptive statistics for each of the four OS occupation groups.) Proficiency in spoken Hebrew is self-

\footnotetext{
${ }^{5}$ The LFS population is Israel's permanent population aged 15+, including potential immigrants and permanent residents residing abroad for up to one year. Sampling is conducted in two phases: In phase 1, localities are sampled; in phase 2, households are sampled within localities. Probability of inclusion for each household in the population is approximately $1 \%$. The sample is drawn once a year and divided into four "panels." Panels are interviewed for two consecutive quarters, not interviewed for the next two, and then interviewed for another two consecutive quarters. The sample in each quarter is composed of 4 panels spanning two or three sampling years. See Israel Central Bureau of Statistics (various years) for details.

${ }^{6}$ Computer technicians were surveyed in 8 different companies, programmers in 9 . Twenty gas stations and 18 construction sites were surveyed.
} 
assessed and measured on a scale of 1 to 5 corresponding to the classifications: "not at all," "a little bit," "not so well," "well," and "very well." The average score was 2.96 on entry into the current job and was 3.32 when interviewed.

\section{Methods}

The now standard approach to measuring wage convergence and the effect of fluency on earnings is to estimate an equation of the form:

$$
\ln \left(w_{i t}\right)=\alpha_{i}+\beta_{z_{i}}^{\prime}+\gamma_{x_{i t}}+\delta_{1} y_{i t}+\delta_{2} y_{i t}^{2}+\rho_{1} v_{i t}+\rho_{2} v_{i t}^{2}+\omega h_{i t}+\varepsilon_{i t}
$$

for $\mathrm{i}=1, \ldots, \mathrm{N}$ persons and $\mathrm{t}=1, \ldots, \mathrm{T}$ periods. Here $\mathrm{w}$ is monthly earnings, $\mathrm{x}$ is laborhrEE market experience, $\mathrm{y}$ is years since migration and $\mathrm{v}$ is current job tenure. The variable $\mathrm{h}$ measures Hebrew language proficiency. The individual effect $\alpha_{i}$ represents a time-invariant influence on earnings, which we label "ability."

The coefficients we seek to estimate in (1) are the causal effects of the covariates on wages, that is, those we would recover from the population regression with random assignment. Crosssectional estimates of coefficients will be biased if unobserved ability is correlated with the covariates. The coefficient on Hebrew is especially suspect, since the ability to learn a language will be reflected in $\mathrm{h}$ but may also be correlated with unobserved to ability to earn, $\alpha_{i}$.

This ability bias can be addressed by estimating

$$
\Delta \ln \left(\mathrm{w}_{\mathrm{it}}\right)=\gamma \Delta_{\mathrm{xit}}+\delta_{1} \Delta \mathrm{y}_{\mathrm{it}}+\delta_{2} \Delta \mathrm{y}_{\mathrm{it}}^{2}+\rho_{1} \Delta_{\mathrm{vit}}+\rho_{2} \Delta \mathrm{v}_{\mathrm{it}}^{2}+\omega \Delta \mathrm{h}_{\mathrm{it}}+\Delta \varepsilon_{\mathrm{it}}
$$

for $\mathrm{i}=1, \ldots, \mathrm{N}$ persons and $\mathrm{t}=1, \ldots, \mathrm{T}$ periods. These coefficients can be consistently estimated if $\Delta \varepsilon$, as defined in (2), is uncorrelated with the covariates. That condition implies, in particular, that there is no unobserved individual effect in earnings growth which is correlated with improvements in Hebrew. In other words, we make the strong assumption that 
$\alpha_{i}$ is time-invariant. This would not apply if, for example, match quality and Hebrew knowledge both increased more rapidly for skilled workers.

The unique feature of our data, which makes estimation of (2) feasible, is longitudinal observation of proficiency in Hebrew. We use a retrospective question regarding Hebrew proficiency upon entry into the current job, along with information about entry wage. In this case we can estimate the coefficients of

$$
\Delta \ln \left(\mathrm{w}_{\mathrm{i}}\right)=+\delta_{1} \Delta \mathrm{y}_{\mathrm{i}}+\delta_{2} \Delta \mathrm{y}_{\mathrm{i}}^{2}+\left(\gamma+\rho_{1}\right) \Delta \mathrm{vi}_{\mathrm{i}}+\rho_{2} \Delta \mathrm{v}_{\mathrm{i}}^{2}+\omega \Delta \mathrm{h}_{\mathrm{i}}+\Delta \varepsilon_{\mathrm{i}}
$$

where: (a) the difference operator $\Delta \mathrm{q}$ indicates the difference between the current level of $\mathrm{q}$ and its level on entry into the current job; and (b) $\Delta x=\Delta v$, since the change in experience and tenure are identical within the current job; (c) the return to years since migration, $\delta_{1}$ and $\delta_{2}$, are identified by the assumption that returns to experience and tenure are identical for immigrants and natives. Alternatively, $\delta_{1}$ can be viewed as the difference in the return to within-job tenure received by immigrants.

Several important points should be recognized about (3). First, in contrast with most panel estimation, the time between observations varies across individuals in our sample. Thus, the change in tenure/experience varies across individuals, and it is possible to identify their joint effect: $\left(\gamma+\delta_{1}\right)$

Secondly, in many cases differencing noisy data generates considerable bias, because it increases the noise-to-signal ratio. Hebrew proficiency is especially subject to measurement error, because proficiency is graded on a scale with only five values. In Dustmann and van Soest (1998a,b) differencing would have resulted in a $\Delta \mathrm{h}$ variable that was almost completely noise. In our case, information about present and previous Hebrew ability is collected simultaneously. Measurement error in the two variables is likely to be highly correlated so that differencing may actually reduce the noise-to-signal ratio. 
Finally, note that all variation in years since migration, $y$, in this differenced sample comes from work years within a job. Thus, $\delta_{1}$ estimates a differential return to tenure between immigrants and natives, excluding the possibility of increasing earnings or accumulating human capital by switching jobs or by residing in the country without working. On the one hand, this rules out investigating the returns to a potentially important role of language skill in job search. On the other hand, it eliminates the possibility of spurious correlation between language skill and quality of job match due to the fact that they both may increase with search time.

\section{Results}

Table 2 reports estimates of the standard cross-sectional human capital earnings function. The first function of the table is to check whether the wage growth of the OS immigrants is comparable to those in the IS, conditional on covariates. Column (1) reports the typical specification in the IS, including both linear and quadratic terms in YSM (years since migration) to allow for a concave profile of earnings. Column (2) reports the same specification estimated in the OS. The coefficient estimates on YSM and YSM squared are statistically the same across the two datasets. While the IS YSM profile is steeper and has less curvature, this difference is largely due to unusually low coefficients in the IS for schooling and labor force experience (including a negative return to experience abroad in the older IS sample). Except for the puzzling contrast in marriage premia between the OS and the IS, and the low OS returns to experience, which may be due to the occupations chosen, the other coefficients are statistically the same in columns (1) and (2). Both sources indicate rapid and concave wage growth with time in Israel, at rates higher than those reported for other immigrant cohorts to Israel (Chiswick, 1998, Friedberg, 1995), but consistent with the findings of Eckstein and Weiss (1998) for the 1990s arrival cohort. 
The remaining columns of Table 2 use the OS to address issues relating to cross-section estimates of wage convergence. Column (3) reports the result of adding 3 occupation indicators to the estimating equation, which greatly increases the precision of estimates. However, it has little effect on estimated wage growth due to years since migration. Based on this crosssectional evidence (in this sample, at least), job mobility does not seem to be a major source of wage convergence.

Columns (4) and (5) add linear and quadratic terms in tenure, respectively. These indicate that about half of the estimated return to YSM is actually due to increasing tenure.

Table 3 uses the standard cross-section approach to investigate how much of those gains in earnings are due to increased proficiency in Hebrew. Column (1) reproduces column (5) of Table 2 for comparison, with linear and quadratic terms in both YSM and tenure. Column (2) reports the results of adding Hebrew proficiency to the equation. The Hebrew variable has a large, positive and precisely estimated coefficient of 0.065 — predicting a $26 \%$ higher wage for an immigrant with a the maximum score (of 5) over a comparable immigrant with the minimum score (of 1). Including Hebrew in the regression reduces the estimated return to tenure by about $1 / 3$, evaluated at the mean, but has no appreciable effect on the estimated effect of years since migration.

As discussed above, the estimated effect of Hebrew fluency on wages may be biased if more able workers are more likely to know Hebrew. To address this issue in column (4) of Table 3 we exploit the availability of longitudinal information about language proficiency for immigrants. These data allow us to estimate equation (3), the differenced version of the humancapital earnings function, reported here for immigrants only. We estimate a large, statistically significant return to Hebrew even after allowing for an individual "ability" effect in earnings. The coefficient is 0.057 , or a predicted $5.7 \%$ increase in wages for each unit of Hebrew proficiency on the 4 -step scale. This coefficient predicts a $23 \%$ increase in earnings associated 
with fluency in Hebrew. The size of this coefficient on Hebrew is striking, considering that we have allowed for ability bias.

Though large, the estimated coefficient on Hebrew in the differenced equation is somewhat smaller than that in the cross-section, suggesting either ability bias in the cross-sectional estimate or an exacerbation of classical measurement error in differences. The retrospective setup argues against the latter explanation, since measurement error in self-reported Hebrew proficiency is probably fairly constant over time for the same individual, making attenuation bias smaller in the differenced equation than in the cross-section. ${ }^{7}$

We return to an analysis of the potential effects of measurement errors in the discussion of occupation-specific estimates below.

Since we cannot identify the normal return to tenure/experience, Table 3 does not allow us to address the role of Hebrew fluency in explaining faster wage growth among immigrants than among natives. In Table 4 we examine both natives and immigrants. We report estimates of equation (3), allowing differential tenure profiles for immigrants and natives. The key questions addressed here are (i) the rate at which immigrants' wages rise compared with natives on the same job and (ii) how much of that wage convergence is due to language acquisition in the first few years after arrival. To emphasize that we are examining differential wage growth within a job, we label our key variable as a tenure-immigrant interaction rather than as YSM. The two variables are, of course, perfectly collinear.

\footnotetext{
${ }^{7}$ There is a form of measurement error in language ability that would bias the differenced coefficient upwards and the cross-sectional coefficient downwards. Since the scale of language ability is bounded at both ends, measurement error could be asymmetric, causing differences in Hebrew to be underestimated and the differenced regression coefficient to be overestimated. This is unlikely as only $4 \%$ of immigrants in the sample report their Hebrew at the lowest level when hired and only $6 \%$ of the sample report their current level of Hebrew as fluent.
} 
As a starting point, column (1) reports cross-sectional estimates of returns to tenure and experience for natives in the OS sample. Column (2) reports that when the same equation is estimated in differences the coefficients are statistically indistinguishable from those in column (1). [Note that $\Delta$ tenure $=\Delta$ experience in our sample, so that the coefficient on tenure in column (2) estimates the sum $\gamma+\rho_{1}$ in equation (3).] We conclude that heterogeneous ability and measurement error are not significant sources of bias in estimating these coefficients for natives.

Columns (3) through (6) report estimates of separate tenure profiles for immigrants and natives. These estimates are from the differenced earnings equation [equation (3)] for a pooled sample of immigrants and natives. The linear specification in column (3) reports a $4.3 \%$ increase in earnings for each year of job tenure for natives. (Recall that this combines both tenure and experience effects.)

Immigrants have an additional 2.2\% increase in earnings per year of job tenure, which reflects the rate at which immigrant wages converge to those of natives, within occupations. This is a relatively fast rate of wage convergence compared to other countries. ${ }^{8}$ How much of that catch-up can be attributed to Hebrew language acquisition? Column (4) reports that adding the linear Hebrew coefficient accounts for most of wage convergence, reducing the differential tenure profile from $2.2 \%$ to $0.9 \%$ per annum, a large and statistically significant decrease. Generalizing the functional form by adding quadratic terms does not change this conclusion, as reported in the bottom row of columns (5) and (6). Language acquisition, estimated here net of a linear ability effect, appears to account for more than half of the wage convergence of recent immigrants within occupations, in our sample.

It is worth noting that our analysis cannot address the contribution of language fluency to wage convergence through occupational change. Weiss and Gotlibovski (1995) examine this

\footnotetext{
${ }^{8}$ The implied within-occupation rate of wage growth in our sample is $6.5 \%$ per year, which
} 
question, finding no significant effect of Hebrew proficiency on the probability of receiving a

job offer. ${ }^{9}$ Weiss, Sauer and Gotlibovski (1999) find that most wage growth in the initial years in Israel occurs within (three) broad occupational categories. While language skills plausibly complement occupational upgrading, we can only speculate on whether they are more important within or between occupations.

\section{Language-skill complementarity}

It seems plausible that language complements some types of human capital more than others, so that the wage gains associated with learning Hebrew will be greater in some jobs. Our survey includes four occupation groups, drawn at opposite ends of the skill distribution: programmers, computer technicians, construction workers and gasoline station attendants. Table 5 reports descriptive statistics for immigrants in each group. Note that the programmers and computer technicians average 15 and 14 years of schooling, respectively, while the lowerskill occupations average less than 12. Job tenure is shorter for the less-skilled workers, though they average about the same amount of time since arrival in Israel, indicating greater turnover in these occupations. Computer technicians' self-reported Hebrew is clearly best, programmers and construction workers have almost the same level, and gas station attendants have the lowest level. The averages for all groups fall between a 3 ("not so well”) and a 4 ("well”). Strikingly, Hebrew fluency at entry is not noticeably higher in high-skill occupations.

We estimate equations (1) and (3) separately for each of the four different occupations. Tables 6 and 7 reveal sharp differences among occupations in both the effects of Hebrew and their importance in explaining wage convergence. Table 6 repeats the cross-sectional and differenced results in Tables 2 and 3 for immigrants in each occupation separately. The first two rows in the left column of Table 6 report those cross-sectional results for programmers and

consistent with the $6.4 \%$ found by Eckstein and Weiss $(1998$, p. 4) for Israel. 
computer technicians, showing that the aggregate patterns are even stronger in these high-skill occupations: the return to "years since migration" is large; and it is almost entirely due to returns to tenure on the current job. The cross-sectional coefficient on Hebrew is quite large: $8.1 \%$ in programmers and $11.2 \%$ for computer technicians. The right hand column reports the coefficient on the change in Hebrew in equation (3), in a differenced specification of the same equation designed to eliminate ability bias. For both programmers and computer technicians the cross-sectional coefficients on Hebrew are statistically indistinguishable from the differenced coefficients.

In contrast, the bottom two rows report that proficiency in Hebrew has little if any effect on the wages of construction workers and gas station attendants. While the cross-sectional coefficients on Hebrew are 3.2 and 3.0 percent, respectively, these coefficients disappear in the differenced specification, indicating that the apparent return to Hebrew language proficiency in the cross-section was due to heterogeneity bias for these two occupations.

The contrast between the high- and low-skill returns to language acquisition is illustrated in the two panels of Figure 1, which plot changes in log wages against changes in Hebrew proficiency once the effects of changes in tenure and years since migration have been removed. (That is, these are plots of residuals from a regression of each differenced variable on the difference in tenure; the slope of a linear regression line for the residuals is the partial regression coefficient by the Frisch-Waugh-Lovell theorem.) Our interpretation of this contrast is that language complements skills in increasing earnings but has no effect on the earnings of less-skilled workers.

Can the estimates from the differenced equation in the right hand column of Table 6 really be interpreted as the effect of Hebrew on earnings and can the contrast between those and the cross-sectional estimates really be interpreted as ability bias? To answer these questions

\footnotetext{
${ }^{9}$ Weiss and Gotlibovski (1995), p. 22.
} 
requires a more complete discussion of two issues pertaining to retrospective measurement of dichotomous variables.

The first issue concerns the bias due to nonclassical measurement error in reporting a continuous variable in a small number of discrete categories. To illustrate the problem, assume that Hebrew proficiency, $\mathrm{h}$, takes on continuous values from .5 to 5.5 and that the answers on the questionnaire are simply rounded to the nearest unit so that for reported Hebrew, $\mathrm{h}^{\mathrm{R}}$,

$$
\mathrm{h}^{\mathrm{R}}=\operatorname{round}(\mathrm{h})=\mathrm{h}+\mathrm{u}
$$

where $\mathrm{u}$ is measurement error. This is nonclassical measurement error, as $\mathrm{u}$ and $\mathrm{h}$ are not independent. Ignoring the other covariates for simplicity,

$$
\ln \left(\mathrm{w}_{\mathrm{it}}\right)=\alpha_{\mathrm{i}}+\omega \mathrm{h}_{\mathrm{it}}+\varepsilon_{\mathrm{it}}=\alpha_{\mathrm{i}}+\omega \mathrm{h}_{\mathrm{it}}^{\mathrm{R}}-\omega_{\mathrm{u}_{\mathrm{it}}}+\varepsilon_{\mathrm{it}}
$$

The bias in least squares regression depends on the correlation of $h^{R}$ and $u$, which, in turn, depends on the distribution of $h$. For example, if $h$ is uniformly distributed on the $[0.5$, 5.5] interval, $\mathrm{h}^{\mathrm{R}}$ and $\mathrm{u}$ are uncorrelated and there will be no bias due to measurement error. If $\mathrm{h}$ has a symmetric central tendency (a lump in the middle), then $\mathrm{h}^{\mathrm{R}}$ and $\mathrm{u}$ tend to be positively correlated since there is more "rounding up" than "rounding down" above the mean and more "rounding down" than "rounding up" below the mean. A positive correlation implies bias towards zero in the estimation of $\omega$. The distribution of $h$ in our data seems to have that central tendency. The distribution of current reported Hebrew by level is $(2 \%, 13 \%, 41 \%, 38 \%$, $6 \%$ ). Fitting that distribution to a normal yields a downward bias of $7.5 \%$ on the estimated coefficient in simulation.

In the differenced equation, on the other hand, the sign of the measurement error bias is ambiguous. The distribution of $\mathrm{h}$ could well have a mass point at zero and is skewed to the right. The distribution of reported change in Hebrew is (no change $-66 \%$, increase of one 
level $-32 \%$, increase of two levels - 2\%). It is plausible that for "no change" rounding is, on average, downward, and that for improved Hebrew rounding is, on average, upward. If so, the measured change understates the true change and the bias in the differenced regression is away from zero, in our case - upwards.

This form of measurement error provides a possible alternative explanation for the pattern reported in Table 6 for the high-skill occupations, since the bias in the cross-sectional estimates is likely toward zero and the bias in the differenced equation is possibly upwards. But if that were the case, we would expect to see the same pattern of estimates for the low-skill occupations as well. The low-skill occupations have similar distributions of changes in Hebrew proficiency, ${ }^{10}$ yet they yield positive estimated coefficients in the cross-section and zeros in first differences. We conclude that bias due to this type of measurement error is unlikely to undermine the central conclusion, that true returns to Hebrew are much higher in high-skill occupations.

A second, related, measurement issue concerns how discrete answers are given in retrospective questions. Assume again that the latent variable is continuous on the $[0.5,5.5]$ interval and that the answer to "current Hebrew" is given according to the rounding formula above. Immediately after answering that question, the respondent is asked to evaluate his Hebrew when he entered the current job. If his current level is $h=3.6$, which he reported as $h^{R}=4$, and the entry level was 3.4 , would he report $h^{R}=3$ following the rule above or $h^{R}=4$ since the change in Hebrew proficiency was only 0.2 ? It is plausible that in this example he reports $\mathrm{h}^{\mathrm{R}}=4$, implying $\Delta \mathrm{h}^{\mathrm{R}}=0$ and generally following a rule that rounds $\Delta \mathrm{h}$ to the nearest integer in reporting $\Delta \mathrm{h}^{\mathrm{R}}$. That practice has two implications for measurement. First, as noted above, changes in Hebrew proficiency are probably measured more precisely than levels (because

\footnotetext{
${ }^{10}$ Low-skill occupations have $70 \%$ no change and $30 \%$ increase by one level, as opposed to $60 \%$ no change, $35 \%$ increase by one level and $4 \%$ increase by two levels for high-skill occupations.
} 
levels involve cross-sectional variation in subjective self-reporting). More broadly, changes and levels are measured in metrics that may be monotone tranforms of one another, but are probably not identical, so that the coefficients of regressions in changes and in levels are not directly comparable. For that reason we are reluctant to interpret the difference between crosssectional and differenced estimates of the return to Hebrew as a precise measure of "ability bias." The data do suggest a positive ability bias in cross-sectional estimates for the low-skill occupations and an absence of such bias in the high-skill occupations, but the precise magnitudes of these biases are indeterminate.

Given our conclusion that improved Hebrew only affects wages for high-skill workers, we return to re-examine differential returns to tenure in each high-skill occupation and evaluate the effect of improved Hebrew. In Table 4 above we saw that on average immigrants had higher returns to tenure than natives, and that over half of the differential was attributable to improved Hebrew, but this estimate combined the impact of Hebrew in high- and low-skill occupations. Table 7a looks at programmers. As in Table 4, equation (3) is estimated allowing a differential slope in the tenure-earnings profile for immigrants. In software earnings growth is 2.6 percentage points higher per year for immigrants [column (1)]. That coefficient is reduced to 0.6 percentage points when changes in Hebrew are included [column (2)] indicating that about $3 / 4$ of that differential in returns to tenure is attributable to improved Hebrew.

Maintaining that this estimated return to Hebrew is free of ability bias requires that the rate at which individuals acquire fluency in Hebrew be uncorrelated with the rate at which other skills appreciate. If fast learners simultaneously learn both programming and Hebrew quickly, we may incorrectly attribute their faster wage growth to their growing Hebrew fluency. We can offer only a partial check on this hypothesis. If more skilled workers learn job-related skills and Hebrew more rapidly, we would expect this to be reflected in faster wage growth within jobs for better educated workers. We therefore tried including education as an explanatory regressor in column (3). The coefficient on education is insignificant, and the remaining coefficients are 
essentially unchanged. The final two columns check robustness to adding a quadratic in tenure and years since migration. In this case Hebrew accounts for $62 \%$ of the differential in returns to tenure, evaluated at the mean.

Table $7 \mathrm{~b}$ reports the same analysis for computer technicians, who have a differential return to tenure of 3.8 percentage points for immigrants, of which between one-half and three-fifths is attributable to improved Hebrew, depending on the specification. Adding years of education has little effect on these results. Taken together, the results for programmers and computer technicians indicate that most of the earnings' convergence by recent immigrants in high-skill occupations is due to language acquisition.

Table 7c repeats this analysis for the low-skill occupations. For construction workers and gas station attendants the stark finding is that there is no earnings convergence to explain. While returns to tenure are high, they occur at the same rate for recent immigrants and natives. This is true with or without Hebrew proficiency in the equation.

This contrast in wage convergence between high- and low-skill occupations has been noted by Eckstein and Weiss (1998), who attributed it to an increased price (or quality) of imported skill. Our interpretation of that finding is that the faster wage convergence of skilled workers is due not to a secular increase in demand for imported skill, but rather the result of improved language proficiency of skilled workers, since Table 7 reports that skilled workers who did not improve their Hebrew had much slower wage convergence. Language seems to increase the quality or usefulness of foreign human capital. 


\section{Conclusions}

Previous research on the role of host-country-language fluency on the growth of immigrant earnings has been suspect because of possible biases related to the correlation between fluency and unmeasured ability, spurious correlation between duration in the host country and fluency, and measurement error in fluency. Because we observe both wage growth and changes in fluency, the first two biases do not arise in our work. Because our data set asks questions about present and past fluency simultaneously, it is likely to be subject to less measurement error in individual assessments of what constitutes a "good" knowledge of a language. Finally, because we examine wage growth within jobs, our findings do not confound the effects of job-shopping with those of increased fluency.

Our results are nevertheless subject to caveats. First, language should be understood as a proxy for a range of host-country skills. ${ }^{11}$ As individuals master the language, they also master social rules and local customs. Second, language may play an important role in determining the type of occupation immigrants can enter. Since we have shown that language plays a more important role in some occupations than in others, we would expect individuals who are fluent in the host country language to select into occupations that are more language-intensive. Moreover, since language and skill level are complementary, increasing fluency should help individuals obtain higher paying jobs. In the cross-section, this effect appears to be small. The coefficient on Hebrew falls from 0.080 to 0.065 when we include occupation dummies. Nevertheless, our estimates almost certainly underestimate the full value of Hebrew knowledge for immigrants.

While not focused on the debate over whether immigrants' earnings overtake those of natives, our two main results nevertheless cast light on this debate. We find significantly greater wage growth for immigrants in certain occupations and a mechanism that supports this

\footnotetext{
${ }^{11}$ The results in Weiss, Sauer and Gotlibovski (1999) suggest that one of these local skills may be English.
} 
faster wage growth. On the other hand, at least for our sample, the faster wage growth and mechanism are confined to relatively high-skill workers. The prevalence of catch-up and surpassing of native workers may depend on the skill level. Skilled workers may be more likely to surpass otherwise comparable natives with similar skills, while unskilled workers may be less likely to do so.

Finally, the results serve to remind us of the economic importance of language. Language may well be the most important public good/infrastructure in a society. It is nonrivalrous and provides network externalities. If so, there may be underinvestment in language skills in competitive equilibrium, especially by immigrants. Supporting language classes for immigrants may not only speed their economic assimilation but may also provide a social benefit.

They find that estimated returns to English language proficiency increase in occupational level. 


\section{References}

Beenstock, Michael (1993). Learning Hebrew and Finding a Job: An Econometric Analysis of Immigrant Absorption in Israel. Jerusalem: The Maurice Falk Institute for Economic Research in Israel, Discussion Paper No. 93.05.

and Yitzhak ben Menahem (1995). The Labor Market Absorption of CIS Immigrants to Israel: 1989-94. Jerusalem: The Maurice Falk Institute for Economic Research in Israel, Discussion Paper No. 95.06.

Belli, Robert F., William Shay, and Frank Stafford (1999). "Event History Calendar Methods Study: Experimental Design, Analytical and Operational Results." University of Michigan, mimeo.

Borjas, George J. (1985). "Assimilation, Changes in Cohort Quality, and the Earnings of Immigrants," Journal of Labor Economics, 3 (4): 463-89.

_ (1987). "Self-Selection and the Earnings of Immigrants," American Economic Review, 77(No. 4, September): 531-53.

_ (1994). "The Economics of Immigration," Journal of Economic Literature, 32(4):16671717.

Carliner, Geoffrey (1980). "Wages, Earnings and Hours of First, Second and Third Generation American Males," Economic Inquiry, 18 (January): 87-102.

_ (1996). "The Wages and Language Skills of U.S. Immigrants,” NBER Working Paper No. $\quad 5763$.

— (2000). "The Language Ability of U.S. Immigrants: Assimilation and Cohort Effects," International Migration Review, 34(1) (Spring): 158-182.

Chiswick, Barry R. (1978). "The Effect of Americanization on the Earnings of Foreign-Born Men," Journal of Political Economy, 86: 897-921.

— (1998). "Hebrew Language Usage: Determinants and Effects on Earnings Among Immigrants to Israel," Population Economics, 11: 253-271. 
and Paul W. Miller (1992). "Language in the Labor Market: The Immigrant Experience in Canada and the United States." In Barry R. Chiswick (ed.), Immigration, Language and Ethnic Issues: Canada and the United States. Washington, DC: American Enterprise Institute, pp. 229-96.

— and — (1999). "Language Skills and Earnings Among Legalized Aliens.” Journal of Population Economics 12: (1) (February) 63-89.

Duleep, Harriet Orcutt and Mark C. Regets (1996). "The Elusive Concept of Immigrant Quality.” Urban Institute, unpublished.

Dustmann, Christian (1999). “Temporary Migration, Human Capital and Language Fluency of Migrants," Scandinavian Journal of Economics, 101: (2) 297-314.

— and Arthur van Soest (1998a). "Language Fluency and Earnings Estimation with Misclassified Language Indicators.” Tilburg: CER Discussion Paper.

— and — (1998b). "Language and the Earnings of Immigrants.” CEPR Discussion Paper. Eckstein, Zvi and Yoram Weiss (1998). “The Absorption of Highly Skilled Immigrants: Israel 1990-1995,” Tel Aviv University, unpublished.

Friedberg, Rachel (1992). “The Labor Market Assimilation of Immigrants in the United States: The Role of Age at Arrival.” Brown University, unpublished.

— (1997). “The Impact of Mass Migration on the Israeli Labor Market.” Brown University, Population Studies and Training Center Working Paper No. 97-11.

_ (2000). "You Can't Take it With You? Immigrant Assimilation and the Portability of Human Capital: Evidence from Israel.” Journal of Labor Economics 18 (2) (April) pp. 221-251.

Hayfron, John E. (1997). "Language Training, Language Proficiency and Earnings of Immigrants in Norway." University of Bergen, unpublished.

Israel Central Bureau of Statistics (various years). Income Survey. Jerusalem. 
LaLonde R. and R. Topel (1991). "Immigrants in the American Labor Market: Quality, Assimilation and Distributional Effects," American Economic Review, 81: 297-302.

Siniver, Erez (1998). "Russian Immigration to Israel.” PhD thesis, Boston University.

Weiss, Yoram and Menachem Gotlibovski (1995). "Immigration, Search and Loss of Skill." Tel Aviv: Foerder Institute Working Paper 34-95.

, Robert M. Sauer and Menachem Gotlibovski (1999). "Immigration, Search and Loss of Skill.” Tel Aviv: Foerder Institute Working Paper 26-99. 
Table 1. Male Immigrants from the former Soviet Union to Israel: Occupation and Income Surveys

\begin{tabular}{|c|c|c|c|c|}
\hline & \multicolumn{2}{|c|}{ Occupation Survey } & \multicolumn{2}{|c|}{ Israel Income Survey } \\
\hline & Mean & $\begin{array}{c}\text { Std. } \\
\text { deviation }\end{array}$ & Mean & $\begin{array}{c}\text { Std. } \\
\text { deviation }\end{array}$ \\
\hline Age & 29.8 & 4.8 & 39.4 & 11.8 \\
\hline Years of education & 12.9 & 2.5 & 13.7 & 3.1 \\
\hline Labor force experience & 10.9 & 4.9 & 19.8 & 11.5 \\
\hline Years since migration & 3.1 & 1.3 & 3.0 & 1.3 \\
\hline (Years since migration) $^{2}$ & 11.0 & 7.7 & 11.0 & 8.1 \\
\hline Currently married & 0.79 & 0.41 & 0.80 & 0.40 \\
\hline Job tenure & 1.3 & 1.1 & - & - \\
\hline$(\text { Job tenure })^{2}$ & 3.0 & 4.0 & - & - \\
\hline Current Hebrew $^{\mathrm{a}}$ & 3.32 & 0.87 & - & - \\
\hline Entry Hebrew $^{\mathrm{a}}$ & 2.96 & 0.87 & - & - \\
\hline Monthly earnings ${ }^{b}$ & 2,168 & 587 & 2,838 & 1,665 \\
\hline Log earnings & 7.649 & 0.250 & 7.793 & 0.605 \\
\hline \multicolumn{5}{|l|}{ Occupation (OS) } \\
\hline Programmers & 0.22 & & & \\
\hline Technician & 0.25 & & & \\
\hline Construction & 0.24 & & & \\
\hline Gasoline station & 0.29 & & & \\
\hline \multicolumn{5}{|l|}{ Occupation (IS) } \\
\hline Scientist/Academic & & & 0.13 & \\
\hline Professional/Technician & & & 0.09 & \\
\hline Manager & & & 0.004 & \\
\hline Clerical & & & 0.03 & \\
\hline Sales & & & 0.03 & \\
\hline Service & & & 0.10 & \\
\hline Agricultural & & & 0.12 & \\
\hline Skilled in Industry & & & 0.25 & \\
\hline Skilled in Services & & & 0.11 & \\
\hline Unskilled \& Production & & & 0.12 & \\
\hline Survey Year & 1994 & 0 & 1994.1 & 0.81 \\
\hline No. of observations & \multicolumn{2}{|c|}{348} & \multicolumn{2}{|c|}{1430} \\
\hline
\end{tabular}

${ }^{a}$ Hebrew knowledge is measured on a scale of 1 to 5 . Entry level Hebrew is the Hebrew score on entry into the current job, as reported retrospectively.

b 1994 New Israeli Shekel (about US\$ 0.30).

Source: Occupation Survey data collected by Siniver in 1994. Israel Income Survey microdata. 
Table 2. Returns to Tenure, in Israel and in Current Job, Evidence from Occupation and Income Surveys - Recent Immigrants

\begin{tabular}{|c|c|c|c|c|c|}
\hline \multirow[b]{2}{*}{$\begin{array}{l}\text { Left-hand variable: Logarithm } \\
\text { of monthly earnings }\end{array}$} & \multirow{2}{*}{$\begin{array}{l}\text { Israel Income } \\
\text { Survey }{ }^{\mathrm{a}} \\
\text { (1) }\end{array}$} & \multicolumn{4}{|c|}{ Occupation Survey } \\
\hline & & (2) & (3) & (4) & (5) \\
\hline Years since migration (YSM) & $\begin{array}{c}0.130 \\
(0.052)\end{array}$ & $\begin{array}{c}0.090 \\
(0.046)\end{array}$ & $\begin{array}{c}0.114 \\
(0.021)\end{array}$ & $\begin{array}{c}0.086 \\
(0.019)\end{array}$ & $\begin{array}{c}0.067 \\
(0.020)\end{array}$ \\
\hline$(\mathrm{YSM})^{2}$ & $\begin{array}{l}-0.009 \\
(0.009)\end{array}$ & $\begin{array}{l}-0.011 \\
(0.008)\end{array}$ & $\begin{array}{l}-0.014 \\
(0.004)\end{array}$ & $\begin{array}{l}-0.012 \\
(0.003)\end{array}$ & $\begin{array}{c}-0.009 \\
(0.003)\end{array}$ \\
\hline Tenure & & & & $\begin{array}{r}0.055 \\
(0.006)\end{array}$ & $\begin{array}{c}0.097 \\
(0.015)\end{array}$ \\
\hline Tenure $^{2}$ & & & & & $\begin{array}{l}-0.012 \\
(0.004)\end{array}$ \\
\hline Years of schooling & $\begin{array}{c}0.023 \\
(0.006)\end{array}$ & $\begin{array}{c}0.050 \\
(0.005)\end{array}$ & $\begin{array}{l}-0.001 \\
(0.003)\end{array}$ & $\begin{array}{l}-0.001 \\
(0.003)\end{array}$ & $\begin{array}{l}-0.0005 \\
(0.003)\end{array}$ \\
\hline Labor force experience & $\begin{array}{l}-0.007 \\
(0.002)\end{array}$ & $\begin{array}{c}0.007 \\
(0.003)\end{array}$ & $\begin{array}{c}0.002 \\
(0.002)\end{array}$ & $\begin{array}{c}0.002 \\
(0.002)\end{array}$ & $\begin{array}{c}0.001 \\
(0.001)\end{array}$ \\
\hline Married & $\begin{array}{c}0.446 \\
(0.050)\end{array}$ & $\begin{array}{l}-0.033 \\
(0.026)\end{array}$ & $\begin{array}{l}-0.005 \\
(0.015)\end{array}$ & $\begin{array}{l}-0.006 \\
(0.013)\end{array}$ & $\begin{array}{l}-0.008 \\
(0.013)\end{array}$ \\
\hline Programmers & & & $\begin{array}{c}0.620 \\
(0.021)\end{array}$ & $\begin{array}{c}0.593 \\
(0.018)\end{array}$ & $\begin{array}{c}0.593 \\
(0.018)\end{array}$ \\
\hline Technician & & & $\begin{array}{c}0.231 \\
(0.019)\end{array}$ & $\begin{array}{c}0.187 \\
(0.017)\end{array}$ & $\begin{array}{c}0.189 \\
(0.018)\end{array}$ \\
\hline Construction $^{\mathrm{b}}$ & & & $\begin{array}{c}0.187 \\
(0.015)\end{array}$ & $\begin{array}{c}0.194 \\
(0.014)\end{array}$ & $\begin{array}{r}0.189 \\
(0.014)\end{array}$ \\
\hline Constant & $\begin{array}{c}6.95 \\
(0.107)\end{array}$ & $\begin{array}{c}6.802 \\
(0.093)\end{array}$ & $\begin{array}{c}7.208 \\
(0.056)\end{array}$ & $\begin{array}{c}7.227 \\
(0.052)\end{array}$ & $\begin{array}{c}7.227 \\
(0.050)\end{array}$ \\
\hline Root mean sq. error & 0.56 & 0.22 & 0.12 & 0.10 & 0.10 \\
\hline $\mathrm{R}^{2}$ & 0.15 & 0.25 & 0.79 & 0.83 & 0.84 \\
\hline No. of observations & 1,430 & & 34 & & \\
\hline
\end{tabular}

Figures in parentheses are heteroskedasticity-consistent standard errors.

${ }^{\mathrm{a}}$ Income Survey regressions include 2 year indicators.

${ }^{\mathrm{b}}$ Omitted occupation is gas station attendants.

Sources: Workplace Occupation Survey conducted in 1994; Israel Income Survey micro data, 19931995. 
Table 3. Returns to Hebrew and Ability: Occupation Survey — Recent Immigrants

\begin{tabular}{|c|c|c|c|c|c|c|}
\hline & \multicolumn{3}{|c|}{ Logarithm of monthly earnings } & \multicolumn{2}{|c|}{$\begin{array}{l}\text { Change in logarithm } \\
\text { of monthly earnings } \\
\text { - current job }\end{array}$} & \multirow[t]{2}{*}{$\begin{array}{l}\text { Explanatory } \\
\text { Variables - } \\
\text { Columns } 4 \& 5\end{array}$} \\
\hline & (1) & (2) & (3) & (4) & $(5)$ & \\
\hline Hebrew & & $\begin{array}{l}0.065 \\
(0.006)\end{array}$ & & $\begin{array}{r}0.057 \\
(0.008)\end{array}$ & $\begin{array}{c}0.058 \\
(0.008)\end{array}$ & $\Delta$ Hebrew \\
\hline \multicolumn{7}{|l|}{ Hebrew level ${ }^{\mathrm{a}}$} \\
\hline 2 - "a little bit" & & & $\begin{array}{r}0.086 \\
(0.027)\end{array}$ & & & \\
\hline $3-$ "not so well" & & & $\begin{array}{l}0.148 \\
(0.027)\end{array}$ & & & \\
\hline 4 - "well" & & & $\begin{array}{c}0.194 \\
(0.027)\end{array}$ & & & \\
\hline 5 - "very well" & & & $\begin{array}{c}0.314 \\
(0.034)\end{array}$ & & & \\
\hline $\begin{array}{l}\text { Years since migration } \\
\text { (YSM) }\end{array}$ & $\begin{array}{c}0.067 \\
(0.020)\end{array}$ & $\begin{array}{r}0.047 \\
(0.019)\end{array}$ & $\begin{array}{c}0.045 \\
(0.019)\end{array}$ & $\begin{array}{c}0.059 \\
(0.003)\end{array}$ & $\begin{array}{c}0.058 \\
(0.008)\end{array}$ & $\begin{array}{l}\Delta \text { tenure } \\
(=\Delta \mathrm{YSM} \\
=\Delta \text { experience })\end{array}$ \\
\hline$(\mathrm{YSM})^{2}$ & $\begin{array}{l}-0.009 \\
(0.003)\end{array}$ & $\begin{array}{l}-0.006 \\
(0.003)\end{array}$ & $\begin{array}{l}-0.006 \\
(0.003)\end{array}$ & & $\begin{array}{c}0.003 \\
(0.002)\end{array}$ & $\Delta \mathrm{YSM}^{2}$ \\
\hline Tenure & $\begin{array}{r}0.097 \\
(0.015)\end{array}$ & $\begin{array}{r}0.057 \\
(0.013)\end{array}$ & $\begin{array}{c}0.056 \\
(0.013)\end{array}$ & & & \\
\hline$(\text { Tenure })^{2}$ & $\begin{array}{l}-0.012 \\
(0.004)\end{array}$ & $\begin{array}{l}-0.006 \\
(0.004)\end{array}$ & $\begin{array}{l}-0.005 \\
(0.004)\end{array}$ & & $\begin{array}{l}-0.002 \\
(0.001)\end{array}$ & $\Delta$ Tenure $^{2}$ \\
\hline Yrs. of schooling & $\begin{array}{l}-0.0005 \\
(0.003)\end{array}$ & $\begin{array}{c}0.001 \\
(0.003)\end{array}$ & $\begin{array}{r}0.001 \\
(0.003)\end{array}$ & & & \\
\hline LF experience & $\begin{array}{c}0.001 \\
(0.001)\end{array}$ & $\begin{array}{c}0.001 \\
(0.001)\end{array}$ & $\begin{array}{c}0.001 \\
(0.001)\end{array}$ & & & \\
\hline Married & $\begin{array}{l}-0.008 \\
(0.013)\end{array}$ & $\begin{array}{l}-0.006 \\
(0.012)\end{array}$ & $\begin{array}{l}-0.006 \\
(0.012)\end{array}$ & & & \\
\hline Constant & $\begin{array}{l}7.227 \\
(0.089)\end{array}$ & $\begin{array}{r}7.064 \\
(0.053)\end{array}$ & $\begin{array}{c}7.123 \\
(0.053)\end{array}$ & $\begin{array}{l}-0.004 \\
(0.003)\end{array}$ & $\begin{array}{l}-0.0001 \\
(0.002)\end{array}$ & Constant \\
\hline 3 occ. indicators & $\checkmark$ & $\checkmark$ & $\checkmark$ & & & \\
\hline Root MSE & 0.10 & 0.09 & 0.09 & 0.56 & 0.55 & Root MSE \\
\hline $\mathrm{R}^{2}$ & 0.84 & 0.88 & 0.88 & 0.68 & 0.68 & \\
\hline No. of observations & 348 & 348 & 348 & 348 & 348 & Observations \\
\hline
\end{tabular}

Figures in parentheses are heteroskedasticity-consistent standard errors.

p-value of test for linearity: 0.0501 .

a The omitted category is level 1 - "not at all."

Sources: Workplace Occupation Survey conducted in 1994. 
Table 4. Returns to Tenure and Hebrew: Occupation Survey Recent Immigrants and Natives

\begin{tabular}{|c|c|c|c|c|c|c|c|}
\hline & \multirow{3}{*}{$\begin{array}{c}\text { Logarithm } \\
\text { of monthly } \\
\text { earnings, } \\
\text { natives } \\
\text { (1) }\end{array}$} & \multicolumn{5}{|c|}{$\begin{array}{c}\text { Change in logarithm of monthly earnings on } \\
\text { current job }\end{array}$} & \multirow{3}{*}{$\begin{array}{l}\text { Explanatory } \\
\text { Variables - } \\
\text { Columns 2-6 }\end{array}$} \\
\hline & & \multirow{2}{*}{$\begin{array}{l}\text { Natives } \\
\text { (2) }\end{array}$} & \multicolumn{4}{|c|}{ Immigrants and natives } & \\
\hline & & & (3) & (4) & (5) & (6) & \\
\hline \multirow[t]{2}{*}{ Hebrew } & & & & $\begin{array}{c}0.054 \\
(0.008)\end{array}$ & & $\begin{array}{c}0.058 \\
(0.008)\end{array}$ & $\Delta$ Hebrew \\
\hline & & & $\begin{array}{r}\mathbf{0 . 0 2 2} \\
(0.003)\end{array}$ & $\begin{array}{r}\mathbf{0 . 0 0 9} \\
(0.003)\end{array}$ & $\begin{array}{c}\mathbf{0 . 0 2 6} \\
(0.008) \\
0.003 \\
(0.003)\end{array}$ & $\begin{array}{c}\mathbf{0 . 0 0 2} \\
(0.008) \\
0.006 \\
(0.002)\end{array}$ & $\begin{array}{l}\Delta \text { Tenure } \times \\
\text { Immigrant } \\
\Delta \text { Tenure }^{2} \\
\times \text { Immigrant }^{2}\end{array}$ \\
\hline Tenure & $\begin{array}{r}0.045 \\
(0.007)\end{array}$ & $\begin{array}{r}0.049 \\
(0.003)\end{array}$ & $\begin{array}{c}0.043 \\
(0.001)\end{array}$ & $\begin{array}{c}0.044 \\
(0.001)\end{array}$ & $\begin{array}{r}0.050 \\
(0.003)\end{array}$ & $\begin{array}{r}0.050 \\
(0.003)\end{array}$ & $\Delta$ Tenure \\
\hline Tenure $^{2}$ & $\begin{array}{l}-0.0010 \\
(0.0005)\end{array}$ & $\begin{array}{l}-0.000 \\
(0.0004\end{array}$ & & & $\begin{array}{l}-0.003 \\
(0.001)\end{array}$ & $\begin{array}{l}-0.002 \\
(0.001)\end{array}$ & $\Delta$ Tenure $^{2}$ \\
\hline $\begin{array}{l}\text { Yrs. of } \\
\text { schooling }\end{array}$ & $\begin{array}{c}0.011 \\
(0.003)\end{array}$ & & & & $\begin{array}{l}-0.001 \\
(0.0013\end{array}$ & $\begin{array}{l}-0.001 \\
(0.0012\end{array}$ & $\Delta \mathrm{YSM}^{2}$ \\
\hline LF experience & $\begin{array}{c}0.007 \\
(0.001)\end{array}$ & & & & & & \\
\hline Married & $\begin{array}{c}0.013 \\
(0.012)\end{array}$ & & & & & & \\
\hline Constant & $\begin{array}{c}7.50 \\
(0.041)\end{array}$ & $\begin{array}{r}0.009 \\
(0.004)\end{array}$ & $\begin{array}{c}0.012 \\
(0.003)\end{array}$ & $\begin{array}{r}0.010 \\
(0.003)\end{array}$ & $\begin{array}{c}0.007 \\
(0.002)\end{array}$ & $\begin{array}{c}0.006 \\
(0.002)\end{array}$ & \\
\hline $\begin{array}{l}3 \text { occ. Indi- } \\
\text { cators }\end{array}$ & $\checkmark$ & & & & & & \\
\hline Root MSE & 0.14 & 0.077 & 0.072 & 0.070 & 0.072 & 0.070 & \\
\hline $\mathrm{R}^{2}$ & 0.73 & 0.71 & 0.70 & 0.71 & 0.70 & 0.72 & \\
\hline \multirow[t]{3}{*}{ Observations } & 603 & 603 & 951 & 951 & 951 & 951 & \\
\hline & & \multicolumn{6}{|c|}{ Derivative evaluated at the mean. } \\
\hline & & & $\begin{array}{l}0.022 \\
(0.003)\end{array}$ & $\begin{array}{l}0.009 \\
(0.003)\end{array}$ & $\begin{array}{l}0.022 \\
(0.003)\end{array}$ & $\begin{array}{l}0.009 \\
(0.003)\end{array}$ & $\begin{array}{l}\text { Immigrant } \times \\
\text { (Tenure, } \\
\text { experience), } \\
\text { YSM }\end{array}$ \\
\hline
\end{tabular}

Figures in parentheses heteroskedasticity-consistent standard errors.

Sources: Workplace Occupation Survey, 1994. 
Table 5. Descriptive Statistics by Occupation: Workplace Occupation Survey

\begin{tabular}{|c|c|c|c|c|}
\hline & Programmer & $\begin{array}{l}\text { Computer } \\
\text { technician }\end{array}$ & $\begin{array}{c}\text { Con- } \\
\text { struction } \\
\text { worker }\end{array}$ & $\begin{array}{c}\text { Gasoline } \\
\text { station } \\
\text { attendant }\end{array}$ \\
\hline Age & $\begin{array}{l}31.8 \\
(4.8)\end{array}$ & $\begin{array}{c}30.8 \\
(4.6)\end{array}$ & $\begin{array}{c}27.4 \\
(3.5)\end{array}$ & $\begin{array}{c}29.4 \\
(5.1)\end{array}$ \\
\hline Years of education & $\begin{array}{l}15.1 \\
(0.9)\end{array}$ & $\begin{array}{c}14.0 \\
(0.7)\end{array}$ & $\begin{array}{l}11.8 \\
(2.9)\end{array}$ & $\begin{array}{l}11.3 \\
(2.4)\end{array}$ \\
\hline Labor force experience & $\begin{array}{l}10.8 \\
(4.9)\end{array}$ & $\begin{array}{c}10.9 \\
(4.8)\end{array}$ & $\begin{array}{c}9.6 \\
(4.3)\end{array}$ & $\begin{array}{l}12.1 \\
(5.1)\end{array}$ \\
\hline Years since migration & $\begin{array}{c}2.9 \\
(1.3)\end{array}$ & $\begin{array}{c}3.3 \\
(1.1)\end{array}$ & $\begin{array}{c}3.0 \\
(1.3)\end{array}$ & $\begin{array}{c}3.0 \\
(1.3)\end{array}$ \\
\hline (Years since migration) $^{2}$ & $\begin{array}{l}10.3 \\
(7.7)\end{array}$ & $\begin{array}{l}12.3 \\
(7.1)\end{array}$ & $\begin{array}{l}10.5 \\
(7.9)\end{array}$ & $\begin{array}{l}11.0 \\
(7.9)\end{array}$ \\
\hline Currently married & $\begin{array}{c}0.81 \\
(0.39)\end{array}$ & $\begin{array}{c}0.74 \\
(0.44)\end{array}$ & $\begin{array}{c}0.82 \\
(0.39)\end{array}$ & $\begin{array}{c}0.79 \\
(0.41)\end{array}$ \\
\hline Job tenure & $\begin{array}{c}1.5 \\
(1.2)\end{array}$ & $\begin{array}{c}2.0 \\
(1.2)\end{array}$ & $\begin{array}{c}0.9 \\
(0.6)\end{array}$ & $\begin{array}{c}1.1 \\
(1.0)\end{array}$ \\
\hline$(\text { Job tenure })^{2}$ & $\begin{array}{c}3.7 \\
(4.5)\end{array}$ & $\begin{array}{c}5.3 \\
(4.8)\end{array}$ & $\begin{array}{c}1.1 \\
(1.1)\end{array}$ & $\begin{array}{c}2.0 \\
(3.2)\end{array}$ \\
\hline Current Hebrew ${ }^{a}$ & $\begin{array}{c}3.35 \\
(1.08)\end{array}$ & $\begin{array}{c}3.55 \\
(0.79)\end{array}$ & $\begin{array}{c}3.33 \\
(0.78)\end{array}$ & $\begin{array}{c}3.11 \\
(0.77)\end{array}$ \\
\hline Entry Hebrew ${ }^{a}$ & $\begin{array}{c}2.96 \\
(0.89)\end{array}$ & $\begin{array}{c}3.07 \\
(0.84)\end{array}$ & $\begin{array}{c}3.04 \\
(0.87)\end{array}$ & $\begin{array}{c}2.80 \\
(0.87)\end{array}$ \\
\hline Monthly earnings ${ }^{b}$ & $\begin{array}{l}3,083 \\
(432)\end{array}$ & $\begin{array}{l}2,130 \\
(283)\end{array}$ & $\begin{array}{l}1,993 \\
(230)\end{array}$ & $\begin{array}{l}1,671 \\
(193)\end{array}$ \\
\hline Log earnings & $\begin{array}{c}8.03 \\
(0.14)\end{array}$ & $\begin{array}{c}7.66 \\
(0.13)\end{array}$ & $\begin{array}{c}7.59 \\
(0.12)\end{array}$ & $\begin{array}{c}7.41 \\
(0.12)\end{array}$ \\
\hline Observations & 75 & 87 & 84 & 102 \\
\hline
\end{tabular}

Figures in parentheses are heteroskedasticity robust standard errors.

${ }^{a}$ Hebrew knowledge is measured on a scale of 1 to 5 . Entry level Hebrew is the Hebrew score on entry into the current job, as reported retrospectively. See data appendix for details.

b 1994 New Israeli Shekel (about US\$ 0.30).

Source: Occupation Survey, 1994. 
Table 6. Returns to Hebrew and Ability Bias by Occupation: Occupation Survey - Recent Immigrants ${ }^{\mathrm{a}}$

\begin{tabular}{lcc}
\hline \multirow{2}{*}{$\begin{array}{l}\text { Left-hand variable: } \text { Log } \\
\text { (earnings) }\end{array}$} & \multicolumn{2}{c}{ Coefficients on Hebrew } \\
\cline { 2 - 3 } & Cross-section & First difference \\
\hline \multirow{2}{*}{ Programmers } & 0.081 & 0.083 \\
Computer technicians & $(0.009)$ & $(0.012)$ \\
& 0.112 & 0.104 \\
Construction workers & $(0.013)$ & $(0.009)$ \\
& 0.032 & -0.002 \\
Gas stations & $(0.011)$ & $(0.010)$ \\
& 0.030 & -0.0002 \\
\end{tabular}

Figures in parentheses are heteroskedasticity robust standard errors.

${ }^{a}$ Cross-section specifications include linear and quadratic terms in tenure and YSM, schooling, LF experience and an indicator for currently married as in column (2) of Table 3. First difference specifications include linear and quadratic terms in tenure and a quadratic term in YSM as in column (6) of Table 4.

Sources: Workplace Occupation Survey, 1994. 

Table 7a. Tenure Profiles and Hebrew - Programmers:
Occupation Survey - Recent Immigrants and Natives

\begin{tabular}{|c|c|c|c|c|c|}
\hline Left-hand variable: $\Delta$ Earnings & (1) & (2) & (3) & (4) & $(5)$ \\
\hline$\Delta$ Hebrew & & $\begin{array}{c}0.090 \\
(0.011)\end{array}$ & $\begin{array}{c}0.093 \\
(0.011)\end{array}$ & & $\begin{array}{c}0.083 \\
(0.012)\end{array}$ \\
\hline$\Delta$ Tenure $\times$ Immigrant & $\begin{array}{c}0.026 \\
(0.005)\end{array}$ & $\begin{array}{c}0.006 \\
(0.004)\end{array}$ & $\begin{array}{c}0.006 \\
(0.005)\end{array}$ & $\begin{array}{c}0.074 \\
(0.015)\end{array}$ & $\begin{array}{c}0.038 \\
(0.015)\end{array}$ \\
\hline$\Delta$ Tenure $^{2} \times$ Immigrant & & & & $\begin{array}{c}-0.003 \\
(0.004)\end{array}$ & $\begin{array}{c}0.001 \\
(0.002)\end{array}$ \\
\hline$\Delta$ Tenure & $\begin{array}{c}0.032 \\
(0.002)\end{array}$ & $\begin{array}{c}0.033 \\
(0.002)\end{array}$ & $\begin{array}{c}0.031 \\
(0.003)\end{array}$ & $\begin{array}{c}0.056 \\
(0.004)\end{array}$ & $\begin{array}{c}0.056 \\
(0.004)\end{array}$ \\
\hline$\Delta$ Tenure $^{2}$ & & & & $\begin{array}{l}-0.009 \\
(0.002)\end{array}$ & $\begin{array}{l}-0.008 \\
(0.002)\end{array}$ \\
\hline$\Delta \mathrm{YSM}^{2}$ & & & & $\begin{array}{c}-0.006 \\
(0.002)\end{array}$ & $\begin{array}{l}-0.005 \\
(0.002)\end{array}$ \\
\hline Yrs. of schooling & & & $\begin{array}{l}-0.010 \\
(0.005)\end{array}$ & & \\
\hline Yrs. of schooling $\times$ Immigrant & & & $\begin{array}{l}-0.0003 \\
(0.0005)\end{array}$ & & \\
\hline Constant & $\begin{array}{c}0.022 \\
(0.004)\end{array}$ & $\begin{array}{c}0.020 \\
(0.004)\end{array}$ & $\begin{array}{c}0.176 \\
(0.071)\end{array}$ & $\begin{array}{c}-0.002 \\
(0.003)\end{array}$ & $\begin{array}{c}-0.001 \\
(0.003)\end{array}$ \\
\hline Root MSE & 0.06 & 0.06 & 0.05 & 0.06 & 0.05 \\
\hline $\mathrm{R}^{2}$ & 0.61 & 0.67 & 0.68 & 0.67 & 0.71 \\
\hline No. of observations & 233 & 233 & 233 & 233 & 233 \\
\hline $\begin{array}{l}\text { Derivatives evaluated at the mean } \\
\text { Immigrant } \times(\text { Tenure, experience, } \\
\text { YSM) }\end{array}$ & $\begin{array}{c}0.026 \\
(0.005)\end{array}$ & $\begin{array}{c}0.006 \\
(0.004)\end{array}$ & $\begin{array}{c}0.006 \\
(0.005)\end{array}$ & $\begin{array}{c}0.032 \\
(0.007)\end{array}$ & $\begin{array}{c}0.012 \\
(0.006)\end{array}$ \\
\hline
\end{tabular}

Figures in parentheses are heteroskedasticity robust standard errors.

Source: Workplace Occupation Survey, 1994. 
Table 7b. Tenure Profiles and Hebrew - Computer Technicians: Occupation Survey - Recent Immigrants and Natives

\begin{tabular}{|c|c|c|c|c|c|}
\hline Left-hand variable: $\Delta$ Earnings & $(1)$ & $(2)$ & $(3)$ & (4) & $(5)$ \\
\hline$\Delta$ Hebrew & & $\begin{array}{c}0.102 \\
(0.009)\end{array}$ & $\begin{array}{c}0.104 \\
(0.009)\end{array}$ & & $\begin{array}{c}0.104 \\
(0.009)\end{array}$ \\
\hline$\Delta$ Tenure $\times$ Immigrant & $\begin{array}{c}0.038 \\
(0.004)\end{array}$ & $\begin{array}{c}0.017 \\
(0.004)\end{array}$ & $\begin{array}{c}0.022 \\
(0.005)\end{array}$ & $\begin{array}{c}0.033 \\
(0.016)\end{array}$ & $\begin{array}{l}-0.007 \\
(0.011)\end{array}$ \\
\hline$\Delta$ Tenure $^{2} \times$ Immigrant & & & & $\begin{array}{l}-0.009 \\
(0.007)\end{array}$ & $\begin{array}{l}-0.002 \\
(0.004)\end{array}$ \\
\hline$\Delta$ Tenure & $\begin{array}{c}0.037 \\
(0.002)\end{array}$ & $\begin{array}{c}0.038 \\
(0.002)\end{array}$ & $\begin{array}{c}0.037 \\
(0.002)\end{array}$ & $\begin{array}{c}0.043 \\
(0.004)\end{array}$ & $\begin{array}{c}0.044 \\
(0.004)\end{array}$ \\
\hline$\Delta$ Tenure $^{2}$ & & & & $\begin{array}{c}0.004 \\
(0.002)\end{array}$ & $\begin{array}{c}0.003 \\
(0.002)\end{array}$ \\
\hline$\Delta \mathrm{YSM}^{2}$ & & & & $\begin{array}{c}0.004 \\
(0.003)\end{array}$ & $\begin{array}{c}0.004 \\
(0.002)\end{array}$ \\
\hline Yrs. of schooling & & & $\begin{array}{l}-0.001 \\
(0.004)\end{array}$ & & \\
\hline Yrs. of schooling $\times$ Immigrant & & & $\begin{array}{l}-0.001 \\
(0.001)\end{array}$ & & \\
\hline Constant & $\begin{array}{c}0.018 \\
(0.007)\end{array}$ & $\begin{array}{c}0.013 \\
(0.006)\end{array}$ & $\begin{array}{c}0.037 \\
(0.060)\end{array}$ & $\begin{array}{c}0.008 \\
(0.007)\end{array}$ & $\begin{array}{c}0.006 \\
(0.006)\end{array}$ \\
\hline Root MSE & 0.07 & 0.06 & 0.06 & 0.07 & 0.06 \\
\hline $\mathrm{R}^{2}$ & 0.68 & 0.76 & 0.77 & 0.69 & 0.77 \\
\hline $\begin{array}{l}\text { No. of observations } \\
\text { Derivatives evaluated at the mean }\end{array}$ & 252 & 252 & 252 & 252 & 252 \\
\hline $\begin{array}{l}\text { Immigrant } \times(\text { Tenure, experience, } \\
\text { YSM })\end{array}$ & $\begin{array}{c}0.038 \\
(0.004)\end{array}$ & $\begin{array}{c}0.017 \\
(0.004)\end{array}$ & $\begin{array}{c}0.022 \\
(0.005)\end{array}$ & $\begin{array}{c}0.025 \\
(0.008)\end{array}$ & $\begin{array}{c}0.010 \\
(0.006)\end{array}$ \\
\hline
\end{tabular}

Figures in parentheses are heteroskedasticity robust standard errors.

Source: Workplace Occupation Survey, 1994. 
Table 7c. Tenure Profiles and Hebrew - Construction and Gas Station Attendants: Occupation Survey — Recent Immigrants and Natives

\begin{tabular}{|c|c|c|c|c|}
\hline \multirow[b]{2}{*}{ Left-hand variable: $\Delta$ Earnings } & \multicolumn{2}{|c|}{ Construction } & \multicolumn{2}{|c|}{ Gas station attendants } \\
\hline & (1) & $(2)$ & (1) & $(2)$ \\
\hline$\Delta$ Hebrew & & $\begin{array}{c}0.001 \\
(0.010)\end{array}$ & & $\begin{array}{c}-0.004 \\
(0.011)\end{array}$ \\
\hline$\Delta$ Tenure $\times$ Immigrant & $\begin{array}{c}-0.004 \\
(0.006)\end{array}$ & $\begin{array}{c}-0.004 \\
(0.008)\end{array}$ & $\begin{array}{l}-0.007 \\
(0.005)\end{array}$ & $\begin{array}{l}-0.006 \\
(0.006)\end{array}$ \\
\hline$\Delta$ Tenure & $\begin{array}{c}0.073 \\
(0.005)\end{array}$ & $\begin{array}{c}0.073 \\
(0.005)\end{array}$ & $\begin{array}{c}0.055 \\
(0.002)\end{array}$ & $\begin{array}{r}0.055 \\
(0.002)\end{array}$ \\
\hline Constant & $\begin{array}{c}0.005 \\
(0.003)\end{array}$ & $\begin{array}{c}0.005 \\
(0.003)\end{array}$ & $\begin{array}{c}0.002 \\
(0.006)\end{array}$ & $\begin{array}{c}0.002 \\
(0.006)\end{array}$ \\
\hline Root MSE & 0.04 & 0.04 & 0.07 & 0.07 \\
\hline $\mathrm{R}^{2}$ & 0.61 & 0.61 & 0.82 & 0.82 \\
\hline No. of observations & 181 & 181 & 285 & 285 \\
\hline
\end{tabular}

Figures in parentheses are heteroskedasticity robust standard errors.

Sources: Workplace Occupation Survey conducted in 1994; Israel Income Survey microdata, 19931995. 
Figure 1a. Changes in Earnings and Hebrew:

Programmers and Computer Technicians

(Leverage Plot)

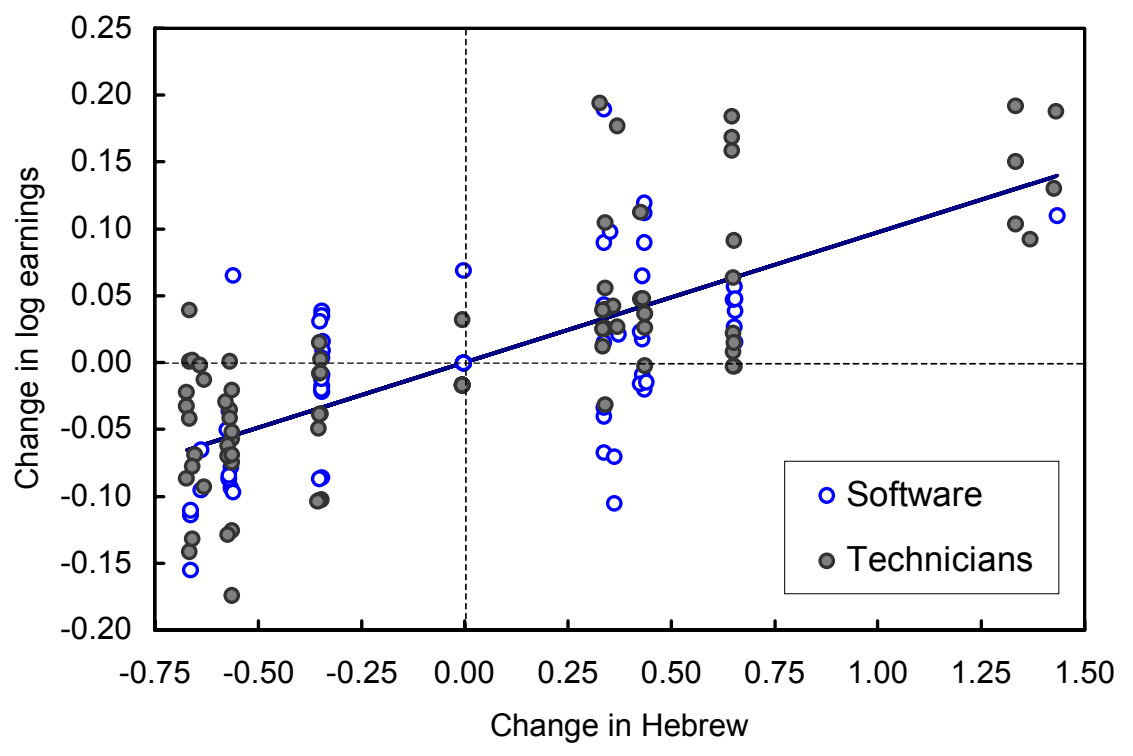

Figure 1b. Changes in Earnings and Hebrew:

Gas Station Attendants and Construction Workers

(Leverage Plot)

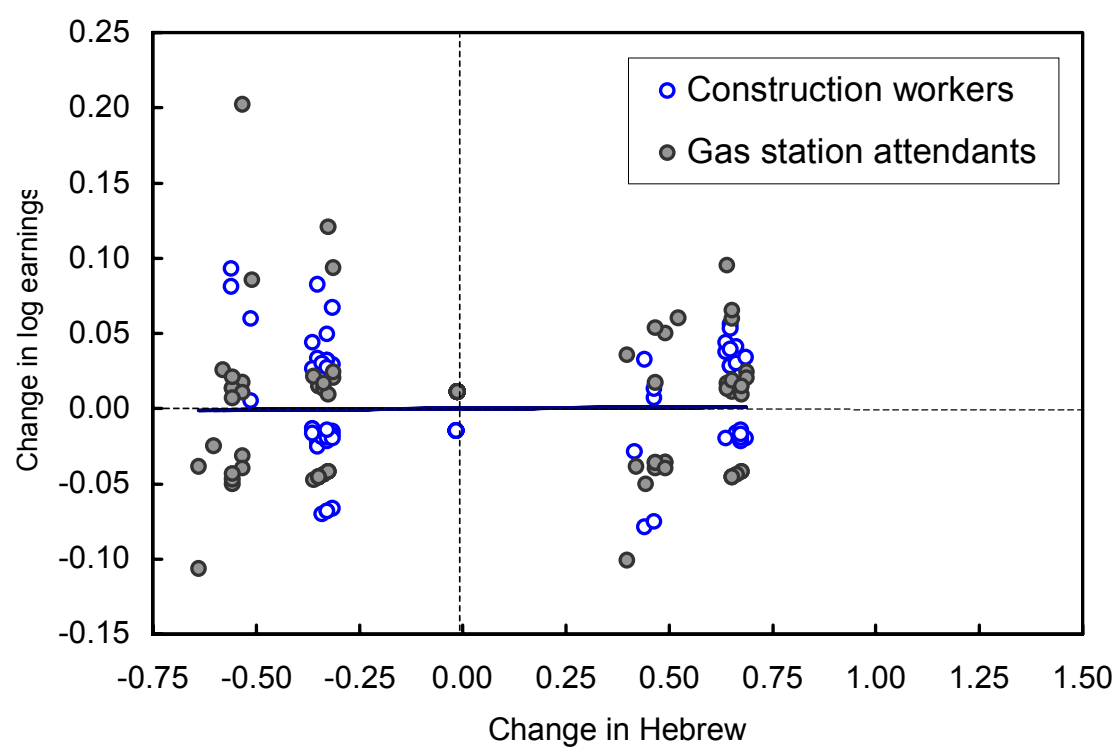

